International Review of Social History 45 (2000), pp. 93-II3

(C) 2000 Internationaal Instituut voor Sociale Geschiedenis

\title{
Poor Jewish Families in Early Modern Rural Swabia
}

\author{
SABINE ULLMANN
}

I

"Jewish protection rights" (Judenschutzrechte) - the legal category according to which Jews were tolerated in a few territories of the old German Empire during the early modern period - made it difficult for Jewish subjects to establish a secure existence. There were, above all, two reasons for this. First, the personalized nature of protection rights enabled the respective authorities to develop selective settlement policies oriented consistently towards the fiscal interests of the state. The direct results of this were increased tributary payments and the withdrawal of one's "protection document" (Schutzbrief) if taxes were not paid. Second, legislators for the territories developed a multiplicity of restrictive decrees concerning the gainful employment of Jews. ${ }^{1}$ Consequently, there were only a few economic niches in which "privileged Jews" (Schutzjuden) were permitted to earn a living. In the countryside - which is where such settlements were mainly situated in the early modern period ${ }^{2}-$ Jews were thus dependent upon peddling foods, textiles and cattle as well as upon lending money. The specific methods of business which developed from this were reflected in the anti-Jewish legend of the deceptive travelling salesman who, by awakening ever new consumer needs, brought his Christian customers into increasing debt. ${ }^{3}$ If one confronts this legend with reality, one finds two characteristic methods of business which arose out of necessity: the cultivation of a varied palette of goods offered, and the development of a differentiated system of payment by instalments. At the same time, these business methods accorded with the

I. On the status of protected Jews (Schutzjuden), see in particular the work of Friedrich J. Battenburg (with references to older articles): Friedrich J. Battenberg, "Rechtliche Rahmenbedingungen jüischer Existenz in der Fruhneuzeit zwischen Reich und Territorium”, in Rolf Kießling (ed.), Judengemeinden in Schwaben im Kontext des Alten Reiches, Colloquia Augustana 2 (Berlin, 1995), pp. 53-79.

2. On this phenomenon in general, see Monika Richarz, "Die Entdeckung der Landjuden. Stand und Probleme ihrer Erforschung am Beispiel Suidwestdeutschlands”, in Karl Heinz Burmeister (ed.), Landjudentum im süddeutschen und Bodenseeraum. Wissenschaftliche Tagung zur Eröffnung des Jiidischen Museums Hohenems 1991, Forschungen zur Geschichte Vorarlbergs II (Dornbirn, 1992), pp. II-22; Monika Richarz and Reinhard Rürup (eds), Judisches Leben auf dem Lande. Studien zur deutsch-jiidischen Geschichte, Schriftenreihe wissenschaftlicher Abhandlungen des Leo Baeck Instituts 56 (Tübingen, 1997).

3. On the formation of stereotypes, see Stefan Rohrbacher and Michael Schmidt, Judenbilder. Kulturgeschichte antijüdischer Mythen und antisemitischer Vorurteile (Reinbek, 1991). 
model of an "economy of makeshift". ${ }^{4}$ In the sense of such "makeshift trade", Jewish peddlers were prepared to travel for days in order to make even the most insignificant profits.

Since both the permission to engage in a trade, and residency rights, depended upon the possession of a "protection document", acquiring such a document assumed a key position in the life plans of Jews. At the same time, the loss of this privilege, or refusal to permit it to be passed on to the next generation, implied the danger of slipping into the status of vagabonding "begging Jews", ${ }^{6}$ not only for the male head of the family, but for the other members of the household as well.

Thus, the basic situation of Jewish families struggling for subsistence differed fundamentally from that of their Christian neighbours. Securing an existence under these difficult conditions - limited settlement possibilities, greater tributary payments and trade restrictions - required a broad repertoire of survival strategies. In this article, I will use the example of Simon and Merle Ulman, a married Jewish couple from Pfersee, to illustrate some of the characteristic risks to which Jewish families were exposed (section III), as well as how these families coped with such risks (section IV). In order to highlight the behavioural patterns, I have consciously chosen a "borderline case", that is, a family which was threatened with the loss of its privileges, but which was able ultimately to avoid a life on the streets - a life which had its own forms of existence, such as vagabonding, begging and petty crime. Thus, my focus is not on members of the so-called "beggar Jewry", who lived on the margins of Jewish society, but rather on a family from the poorest class of those rural Jews who were settled and privileged with a "protection document". My investigation begins with a depiction of the Ulmans' work situation and their financial circumstances, as well as their marital work organization (section II). In a final section, I will discuss

4. On the concept of an "economy of makeshift", see Olwen H. Hufton, The Poor of EighteenthCentury France 1750-1789 (Oxford, 1974), pp. 69-127. See also Jürgen Schlumbohm, Lebensläufe, Familien, Höfe. Die Bauern und Heuerleute des Osnabriuckischen Kirchspiels Belm in protoindustrieller Zeit, I650-1860, Veröffentlichungen des Max-Planck-Instituts für Geschichte no (Göttingen, 1994), pp. 293f.

5. On the radius of activity of Jewish peddlers, see Sabine Ullmann, Nachbarschaft und Konkurrenz: Juden und Christen in Dörfern der Markgrafschaft Burgau, Veröffentlichungen des MaxPlanck-Instituts für Geschichte 151 (Göttingen, 1999), pp. 255-265.

6. Rudolf Glanz, Geschichte des niederen judischen Volkes in Deutschland. Eine Studie uber bistorisches Gaunertum, Bettelwesen und Vagantentum, (New York, 1968), Pp. 60-128; Uwe Danker, Räuberbanden im Alten Reich um 1700. Ein Beitrag zur Geschichte von Herrschaft und Kriminalität in der frühen Neuzeit (Frankfurt/M., 1988), pp. 318-326; Ernst Schubert, Arme Leute, Bettler und Gauner im Franken des I8. Jahrhunderts, Veröffentlichungen der Gesellschaft für fränkische Geschichte Reihe IX, 26 (Neustadt/Aisch, 1983), pp. 169-178; Jacov Guggenheim, "Meeting on the Road: Encounters between German Jews and Christians on the Margins of Society", in Ronnie Po-chia Hsia and Hartmut Lehmann (eds), In and Out of the Ghetto: Jewish-Gentile Relations in Late Medieval and Early Modern Germany (Cambridge, 1995), pp. 125-137. 
several possible consequences which these specific patterns of behaviour had on the structure of Jewish households (section V).

In order to support my interpretation of the case study selected here, I will also draw upon supplementary references to other families throughout the article. However, due to the limitations of existing sources regarding Jewish history, we will have to content ourselves with relatively limited insights into the details of Jewish life at this time. There are several reasons for this. Before the legislation concerning the emancipation of Jews, Jewish legal autonomy dictated that private legal contracts as well as intrafamilial disputes were negotiated before a rabbi. Since the Jewish communal archives in Swabia have been almost completely destroyed, ${ }^{7}$ we are dependent to a great extent upon sources which are Christian in origin. During the course of the eighteenth century, the recording of such documents did increase, as many protected Jews also began to provide evidence of their marital contracts or testaments before Christian courts. However, the use of Christian authorities was by no means generally adopted among Jews, and, even when it was used, Hebrew contracts were often kept by Christian authorities only in summarized translation. Thus, the insights into the intra-Jewish world offered by such sources is often selective. The gainful employment of protected Jews, on the contrary, has been documented much more substantially. We owe the existence of these documents to the legal requirement that Jewish-Christian trade contracts, even for the most insignificant business transactions, be recorded - a measure supposed to protect the Christian population from what was held to be Jewish "profiteering". Although the authoritarian measures in the Swabian territories investigated here by no means provide us with a complete record of documents, they do offer us a significant amount of material about Jewish businesses. In this way, we are able to follow the business dealings of the Ulman family, albeit with interruptions, for the time period between December 1700 and October 1723, with selective references for the years 1686 and 1725 .

Simon and Merle Ulman earned a living in Pfersee primarily as pawnbrokers and merchants, engaging in business with the inhabitants of the imperial city of Augsburg located nearby - a specialization which was typical for this suburban community. ${ }^{8}$ Due to the great concentration of Jewish settlements in this region, the merchants in the Swabian Jewish villages - for whom we are able to make the following observations ${ }^{9}$ - were faced with intra-Jewish

7. Doris Pfister, "Quellen zur Geschichte der Juden in Schwaben", in Peter Fassl (ed.), Geschichte und Kultur der Juden in Schwaben, Irseer Schriften 2 (Sigmaringen, 1994), pp. 9-19.

8. Ullmann, Nachbarschaft und Konkurrenz, pp. 265-268.

9. Rolf Kießling, "Zwischen Vertreibung und Emanzipation - Judendörfer in Ostschwaben während der Frühen Neuzeit", in Kießling, Judengemeinden in Schwaben, pp. 154-183. 
competition, which led to a spatial and functional specialization. While Jews in the so-called suburban communities, such as Pfersee, supplied urban residents with rural goods and money loans, communities located in the provinces, away from urban centres, concentrated above all on doing business with peasants in the surrounding villages. The village Pfersee, situated directly before the gates of the imperial city of Augsburg, was one of the typical "Jewish villages" in Swabia. Around 1700, approximately sixteen per cent of its inhabitants were Jewish. All of them can be characterized as "protected Jews", i.e., they had been granted residential and business privileges.

Judging from the magnitude of the Ulmans' business contracts in the years between 1686 and 1725, as well as from descriptions of the items pawned with them, we can classify their business unambiguously as the most minor retail trade. These documents also reflect the explicitly poor economic situation of the family. The textiles recorded are without exception of inferior quality, the designs so simple that they required no further description. They are usually described tersely as "I coat or I piece gray cloth $^{\text {ro }}{ }^{\text {In }}$ those cases in which there is a more detailed entry, the comments suggest an inferior design, indicated by the predominance of the colours black and brown, and of cotton flannel and wool as materials, as well as the lack of silk and velvet. Pieces of jewellery or more valuable household items were not among the objects pawned with them. ${ }^{\text {II }}$ A dispute with a customer, the craftsman Mathias Mennhofer from Augsburg, reveals that Simon did not always have the necessary capital for his loan business. On 2 January 1772, Mennhofer accused him of not being able to return pawned items - a belt and two bedspreads - which Mennhofer had wanted to redeem for 6 florins. During the course of the court proceedings, we learn that Simon had himself sold the objects to a Jewish man from Kriegshaber before the prescribed expiration date, as he desperately needed the money. The authorities refrained from punishing Simon, but ordered him to buy back the pawned items and to give them to Mennhofer. ${ }^{12}$ In addition to this business, Simon Ulman engaged in a goods trade which is not more precisely described in the records - references to this trade can be found above all in his outstanding debts to businessmen in Augsburg. ${ }^{13}$ The connection between the pawn business and the small goods trade is obvious and has been demonstrated often. Numerous items were pawned with Jewish merchants and then were never bought back. After the expiration of a certain amount of time, these unredeemed items became the property of the

Io. Staatsarchiv Augsburg [hereafter StaatsAA], Reichsstadt Augsburg, Literalien, St. Jakobs Pfrïnde no. 202, fos 90, 98, entries from the year 1686.

II. StaatsAA, Reichsstadt Augsburg, Literalien, St. Jakobs Pfruinde no. 207, fo. 47, entry from the year 1722.

12. Ibid.

13. See section IV of this article. 
Jewish merchants, who could then resell them. From the loans for deposits, a small goods trade developed with these unredeemed items.

Given the conditions described above, it is clear that a Jewish family could not earn a subsistence living through the male head of the household alone. His wife had to work in the family business as well. On numerous occasions, the pawn contracts of Simon's wife were recorded with the bailiff (Dorfvogt). For example, the student Philipp Anton Schmidt pawned "upper and lower beddings" with her for 6 florins and 15 kreuzer. ${ }^{14}$ In concluding the deal, Merle had the authorities confirm that after the expiration of a four-week period the bedclothes would become her property. In 1725 , she reported the purchase of a "poor and completely worn out red coat for the sum of $2 \mathrm{~A}^{x^{x}}{ }^{25}$ Merle was not an isolated case in this respect. In the first two decades of the eighteenth century alone, there are ten Jewish businesswomen in the Pfersee community who appear in the official protocols. For the most part, these cases dealt with business transactions which had led to disputes as the result of lost pawn tickets or unredeemed items. In February 1702, for example, a Jewish woman named Vögelin brought a complaint against a gold-beater from Augsburg, because the latter was more than a year overdue in paying her interest. Vögelin received permission from the bailiff to resell the pawned objects - several pieces of jewellery - in order to compensate for her losses. ${ }^{16}$ In the same year, a Jewish woman named Schenlin reported a pawn deal in which "I green woman's jacket and I black shirt" had been left with her - the deal had been concluded several months ago and the ticket had subsequently been lost. She, too, received permission to resell the articles of clothing. ${ }^{17}$ Although evidence of women's business activities can also be found sporadically in trade with rural goods and cattle ${ }^{\mathrm{IB}}$ the pawn business appears to have played a particularly important role for women. Being a widow was not a precondition for such business activity. Jewish wives also engaged in such transactions.

Michael Toch has repeatedly emphasized the special economic position of women in all social classes in late medieval urban Jewish communities. ${ }^{19}$

14. StaatsAA, Reichsstadt Augsburg, Literalien, St. Jakobs Pfründe no. 207, fo. 47, entry from the year 1722.

15. StaatsAA, Reichsstadt Augsburg, Literalien, St. Jakobs Pfründe no. 207, fo. 360, entry from the year 1725 .

16. StaatsAA, Adel, Literalien, von Langenmantel no. 34, fo. 69v.

17. StaatsAA, Adel, Literalien, von Langenmantel no. 34, fo. 9Iv. See in addition to this, the following entries regarding Jewish business women: StaatsAA, Reichsstadt Augsburg, Literalien, St. Jakobs Pfründe no. 204, fo. 56; no. 207, fos 37, 46, 223, 254, 486; StaatsAA, Adel, Literalien, von Langenmantel no. 34 , fos $20 \mathrm{v}, 46 \mathrm{v}, 92 \mathrm{v}$, 13Iv, $169 \mathrm{r}$.

18. On I6 April 1706, the Jewish woman Köhlin from Pfersee had the courts record a cattle contract which she had made with the peasant Jakob Mayer. See StaatsAA, Adel, Literalien, von Langenmantel no. 34 , fo. $162 \mathrm{v}$.

19. Michael Toch, Die Juden im mittelalterlichen Reich, Enzyklopädie deurscher Geschichte 44 (München, 1998), p. I5; idem, "Die judische Frau im Erwerbsleben des Spätmittelalters", in Julius Carlebach (ed.), Zur Geschichte der jüdischen Frau in Deutschland (Berlin, 1993), pp. 37-48. For 
Evidently this was also true for Jews in village communities in the early modern period. This economic position accords with the image - almost a topos - of the independent Jewish businesswomen in the pre-Assimilation era, an image which we have come to know, for example, through the memoirs of Glückel von Hameln. ${ }^{20}$ Merle's business activities were thus typical for the life conditions of rural Jewish women in the early modern period. They also seem to have been a plausible necessity for a family engaged in the pawn business. Since making rounds through the trade district required extended travel by the husband, local business was probably carried out to a large extent by their wives. The entries in the official protocols of such communities and the regular business contracts with Christian village neighbours demonstrate, in addition to this, that a portion of business life was actually carried out within Jewish villages, and that there were also business deals which were not concluded during such travel on the road.

In spite of their familial cooperation, the Ulmans were able to make only very small profits from their businesses. This is indicated by their position within the social structure of the Jewish village. According to the Pfersee tax list from 1689, Simon Ulman had assets of 700 florins, which placed him among the poorest in his community - only three other protected Jew households had less than this (600 fl., $500 \mathrm{fl}$., and $200 \mathrm{fl}$.). Lazarus Günzburger had the greatest assets in the community with $18,500 \mathrm{fl}$., and a different Ulman family, ${ }^{21}$ who where "court Jews", had assets of 5,000 fl. Simon and Merle's modest living conditions were also reflected in the house they owned. Like most of the Jewish households in Pfersee - only five of which are listed in the records as renters (Beisasse) - the Ulmans owned real estate. ${ }^{22}$ According to the Pfersee property register from 170I, Simon possessed a so-called Selde, a house without agricultural acreage, which was valued at $500 \mathrm{fl}^{23} \mathrm{We}$ find similarly low valuations for a series of other Jewish houses

the early modern period, see Monika Richarz, "In Familien, Handel und Salon. Jüdische Frauen vor und nach der Emanzipation der deutschen Juden", in Karin Hausen and Heide Wunder (eds), Frauengeschichte - Geschlechtergeschichte, Reihe Geschichte und Geschlechter I (Frankfurt/ M. [etc.], 1992), pp. 57-66, 60, and Julius Carlebach, "Family Structure and the Position of Jewish Women", in Werner E. Mosse et al. (eds), Revolution and Evolution: 1848 in German-Jewish History, Schriftenreihe wissenschaftlicher Abhandlungen des Leo-Baeck-Instituts 39 (Tübingen, 198I), Pp. 157-187. See also the critique of Carlebach by Marion Kaplan, "Family Structure and the Position of Jewish Women: A Comment", in ibid., pp. 189-203.

20. Glückel von Hamein, Die Memoiren, aus dem Jildisch-Deutschen von Bertha Pappenheim (1910, new edition Weinheim, 1994). Most recently, Natalie Zemon Davis, Women on the Margins: Three Seventeenth-Century Lives Glikl, Marie de l'Incarnation, Maria Sibylla Merian (Cambridge, 1995). 2I. Sabine Ullmann, "Zwischen Fürstenhöfen und Gemeinde. Die jüdische Hoffaktorenfamilie Ulman in Pfersee während des 18. Jahrhunderts", Zeitschrift des Historischen Vereins für Schwaben, 9o (1998), pp. 159-187.

22. Ullmann, Nachbarschaft und Konkurrenz, appendix no. II.

23. Ibid., p. 533 and appendix no. 14 (Kartenbeilage). 
in the community, several of which were even valued significantly lower than the Ulmans' house. However, the wealthy Löw Simon Ulman had property valued at $1,800 \mathrm{fl}$., again illustrating the significant differences in assets within the community, and placing Simon and Merle's household among the poorer in the community. In 1723 , Simon's house was described as being in a "completely ruinous" condition. ${ }^{24}$ Significantly, Simon also used the epithet "the Small", which allowed him to be distinguished unambiguously from the court Jews of the same name in the village.

\section{I}

Initially the Ulman couple was able make a living and to pay the authorities' tax demands. Only in the winter of 1718 did Merle Ulman decide to disclose their economic crisis. She had the local authorities declare her husband legally incapacitated, and pressed to have the residency rights of his two sons in the village withdrawn. The official village protocol stated that in the future "on directions of his wife, no one should loan him any items or lend him money, and that he should also be requested by officials to remove his two sons from his house so that they earn a living elsewhere ${ }^{25}$ With this, Merle had violated basic norms of traditional Jewish society. She not only provided the Christian authorities with an opportunity to intervene in intraJewish affairs - an occurrence which the leaders of the Jewish community complained about repeatedly ${ }^{26}$ - but demanded, at the same time, the use of an anti-Jewish legal instrument, i.e., the withdrawal of residency privileges. Turning to Christian authorities appears to have had little success initially, as Simon Ulman's business activities are recorded even after this, for example, in January $1722 .{ }^{27}$ Only following the summer of 1723 do his traces disappear from official documents. Whether the sons were actually expelled from the village cannot be determined from the records. On the tax lists from 1722 , there are three children listed in the Ulman household, ${ }^{28}$ but since the sex of these children is not recorded, it is not clear whether these were daughters of the couple or whether they included the two sons.

References to Simon Ulman's business dealings in the Pfersee judicial protocols make Merle's decision perhaps understandable and also indicate that this crisis had a long history. Her husband's first debt contract for over $75 \mathrm{fl}$. dates from 12 December 1700. In 1702, he had to appear before the village administrator's office twice to answer the demands of a creditor, the businessman Andreas Wagner from Kaufbeuren. After Simon was not able to make his payments on time, he was finally forced to take out a mortgage

24. StaatsAA, Reichsstadt Augsburg, Literalien, St. Jakobs Pfründe no. 207, fo. 119.

25. Stadtarchiv Augsburg [hereafter StadtAA], St Jakobs Pfründe, Fach inz Lit. A, fo. I91.

26. Ullmann, Nachbarschaft und Konkurrenz, pp. I92f.

27. StaatsAA, Reichsstadt Augsburg, Literalien, St. Jakobs Pfründe no. 207, fo. 3. See also above.

28. Ullmann, Nachbarschaft und Konkurrenz, pp. 535 f. 
on his house. ${ }^{29}$ Although he did not pay back the mortgage, he was subsequently able to borrow $160 \mathrm{fl}$. on his property again in July 1705 , and on 17 September 1706, Johann Jakob Goldschlager even raised the mortgage another $24 \mathrm{fl} .^{3 \circ}$ By February I7II, Simon's situation had worsened to such an extent that there was supposed to "be a public auction by the authorities due to his many debts", i.e. Simon was threatened with a forced sale of his house. Since another Augsburger merchant, Philipp Heggenauer, was prepared to assume Simon's debts to Goldschlager, the compulsory auction, however, was again delayed. ${ }^{31}$ In spite of this, Simon could not in the end prevent financial ruin. In the following year, the couple was summoned before the bailiff by Andreas Wagner from Kaufbeuren due to an unpaid bill of $50 \mathrm{fl}$. Merle now used her dowry to assume liability for this debt. She signed the contract under the express waiver of her "female privilege", i.e. the right that her own capital remain untouched. ${ }^{32}$ When, in the summer of 1718 , her husband finally pawned their two synagogue seats, Merle filed charges and the conflict between the couple was settled in court. She requested that the bailiff "look into the matter, to find out why the two men and women's school seats had been sold". ${ }^{33}$ The pawning of synagogue seats, admittedly, was not an unusual solution for poor Jewish families. ${ }^{34}$ However, the possession of such seats not only identified the owner as a full member of the Jewish community and provided him with a place in the village hierarchy analogous to the seating arrangement. It was also tied to the enjoyment of honorary functions in the synagogue. For this reason, seats were pawned usually only as a last resort. ${ }^{35}$ In selling the synagogue seats, Simon had crossed a boundary, and provoked Merle to take the respective countermeasure of turning to the Christian authorities. Caught in a spiral of increasing debt, Simon had lost not only his house and a portion of his wife's dowry, but the family's synagogue seats as well, which in addition to their material value - were understood as symbolic capital.

29. StaatsAA, Adel, Literalien, von Langenmantel no. 34, fos 32r, 68, $87 \mathrm{v}, 97 \mathrm{v}$.

30. Ibid., fos $144 \mathrm{r}, \mathrm{I7} 8 \mathrm{r}$.

31. StaatsAA, Reichsstadt Augsburg, Literalien, St. Jakobs Pfründe no. 204, fo. 42.

32. StaatsAA, Reichsstadt Augsburg, Literalien, St. Jakobs Pfrunde no. 204, fo. m. This procedure accords with the Christian practice. On this, see David Warren Sabean, "Allianzen und Listen: Die Geschlechtsvormundschaft im 18. und 19. Jahrhundert", in Ute Gerhard (ed.), Frauen in der Geschichte des Rechts: Von der Fruhen Neuzeit bis zur Gegenwart (Munich, 1997), Pp. 460-479. I owe the reference on the conceptual explanation of "female privilege" (weibliche Freiheit) to Christine Werkstetter. See also her investigation of the legal practice in Augsburg: Christine Werkstetter, "Frauen im Augsburger Zunfthandwerk. Eine Studie zu Arbeit, Arbeitsbeziehungen und Geschlechterverhältnissen im 18. Jahrhundert", (Ph.D. dissertation, Universität Augsburg, 1999).

33. StadtAA, St. Jakobs Pfrinde, Fach 112 Lit. A, fo. 181.

34. Ullmann, Nachbarschaft und Konkurrenz, p. I81.

35. Ismar Elbogen, Der jüdische Gottesdienst in seiner geschichtlichen Entwicklung (Hildesheim, 1995), p. 475 . 
According to Merle, Simon was also no longer in a condition "to continue to support his sons due to his poor health".$^{36}$

This dire financial situation, however, did not develop solely through the couple's own mismanagement. Initially, the crisis was rather an expression of their poverty, as is evident from the economic relations described at the beginning of the article. Yet in addition to this, there is repeated evidence that Simon Ulman's behaviour also caused significant conflict. Twice in the second half of 1718 , the couple's disputes escalated to such a degree that they had to be settled before the Christian court. When, in I723, proceedings began for the compulsory sale of their house, Simon - who could not appear at a number of court dates due to illness - was accused of having repeatedly led a "bad household" (ein böses Hauswesen). In the course of the proceedings, Merle obtained the assurance that in the future she "was responsible for providing him [Simon] with no more than the necessary food and drink for as long as she lived ${ }^{37}$ It is not clear whether the dispute was ultimately aimed at divorce - which was possible according to Jewish $\mathrm{law}^{38}$ - or whether Merle only wanted to secure the revenue of her own business deals from her husband. In any case, illness and family disputes were among the most frequent problems in the Ulman household. At the same time, these problems also reflect - in addition to the structural-causal complex described - the concrete, individual risks which the family faced. Poorer protected Jewish households were not always able to compensate for marital conflicts which prevented a smooth cooperation between the couple in their business, or for the extended loss of work hours of a family member due to illness. As the Jewish peddling trade was organized as a "family business", any disruption which reduced earning possibilities - be it dispute or illness - potentially posed an existential threat to maintaining the family's protection document. At the same time, family disputes were not only the cause of such crises, but could be the consequence of them as well, for example, when no agreement could be reached about the necessary strategies of action or when different interests existed - as in the case of the Ulmans.

Among those events which most frequently threatened a family with the loss of their protection privileges were the death of a spouse and misfortune in the family business. I mention several examples here. Widow households were usually confronted directly with the "necessity of replacing role functions ${ }^{7,}{ }^{39}$ in order to maintain the basis of the family income. The economic situation for such households could become very difficult. Since it was impossible to combine business transactions while travelling with caring for

36. StadtAA, St. Jakobs Pfründe, Fach 112 Lit. A, fo. I9I.

37. StaatsAA, Reichsstadt Augsburg, Literalien, St. Jakobs Pfründe no. 207, fo. 141.

38. On Jewish marital law, see Rachel Monika Herweg, Die jüdische Mutter. Das verborgene Matriarchat (Darmstadt, 1994), pp. 53-65.

39. Michael Mitterauer, Familie und Arbeitsteilung. Historischvergleichende Studien, Bibliothek der Kulturgeschichte 26 (Wien [etc.], 1992), pp. 171-176. 
the household and raising children, it was usually the husband who undertook the necessary business travels within the trade district. Consequently, a merchant household could fall into a sustained crisis following the husband's death - as it could following the wife's death as well. The widow, for example, would now have to make the necessary protection payments as well as earn a living herself without the assistance of her husband.$^{\circ}$ One possible initial solution was to attempt to have the tax payments reduced. Thus, many women in Pfersee sought to receive a reduction in payments through a petition - often with success. On Io February I723, the widow of Henle Ulman, for example, was granted permission by the bailiff to pay a reduced tax of only $12 \mathrm{fl}$. in the future, instead of the original $25 \mathrm{fl} \cdot{ }^{41} \mathrm{In}$ the same way, the Jewish woman Rifga was also granted a reduced residency payment (Sitzgeld) of only 12 $\mathrm{fl}$. in February $1727 .{ }^{42}$ Although we cannot draw any direct conclusions about the actual situations of the households from the descriptions in these petitions, as the rhetorical strategies employed by the women here may have played an important role, their economic plight remains understandable.

Many widows were thus forced to transfer their protection rights as quickly as possible, either to a son or a son-in-law, and then to acquire residency rights in the newly founded household. In June 1728 , for example, the Pfersee protections rights of Lev Ulman's widow were transferred to her son, who established his own household following his marriage to the daughter of the Jewish leader Samuel Liebermann from Höchstadt. ${ }^{43}$ Reduced taxes frequently provided the possibility of maintaining protection privileges until a widow was able to remarry. In several of such tax exemptions, it was stated explicitly that the waiver would only be granted up to the point of "remarriage". ${ }^{44}$ Here, the authorities' interest in having subjects who were as stable and solvent as possible, and who could provide secure revenue, was of central importance. Within the framework of such protection policies, it was entirely possible for authorities to tide over individual households during a financial crisis by allowing for reduced tax and tributary demands. The unambiguous boundaries of such assistance, however, can be seen in those cases in which local authorities no longer recognized any prospects of the household regenerating in the future and thus decided that

40. On this subject, see also Rainer Sabelleck, "Soziale Versorgung von Angehörigen jüdischer Familien in norddeutschen Städten des späten I8. und frühen 19. Jahrhunderts", in Jürgen Schlumbohm (ed.), Familie und Familienlosigkeit. Fallstudien aus Niedersachsen und Bremen vom is. bis 20. Jabrbundert, Quellen und Untersuchungen zur Wirtschafts- und Sozialgeschichte Niedersachsens in der Neuzeit 17 (Hannover, 1993), Pp. 127-130; Rainer Sabelleck, Jidisches Leben in einer nordwestdeutschen Stadt: Nienburg, Veröffentlichungen des Max-Planck-Instituts für Geschichte 99, (Göttingen, 1991), pp. 83 f.

4I. StadtAA, St. Jakobs Pfründe, Fach II8 Fasz. A, fo. 120.

42. Ibid., fo. 158 .

43. Ibid., fo. 161 .

44. See for example, StadtAA, St. Jakobs Pfründe, Fach In Lit A, fo. 239. 
a valuable source of revenue had been lost. The widow of Simon Weil, for example, was initially granted reduced widow protection money. However, when she was not able to remarry or to improve her financial situation in another way, she was finally forced to leave Pfersee in March $1719 .^{45}$ In October 1743, the widow Marium appeared before the bailiff of the same locality, and unsuccessfully requested a waiver of her protection money "because her husband David has been dead for six years and left her nothing other than [the possibility of] begging". Because of her poor health, she continued, she was not even able to beg daily and now "had to suffer the greatest misery in her old age $e^{\prime}$ A note in the margins of the document records that she was expelled from the community. ${ }^{46}$ The fate of these two women indicates that the death of a husband could lead to the loss of protection privileges. Regardless of their economic position, widows thus belonged to a group which was particularly at risk.

A final example from Binswangen - a Jewish settlement in Swabia removed from urban centres - illustrates the direct consequences of illness and accident for families in lower-income groups. The business dealings of a protected Jew named Mayer can be followed in the Binswangen village protocols from 1662 to I68I. Mayer concentrated initially on the cattle trade; in addition to this, he provided loans for various items and sold grain, vegetables, fruit and wood as well as iron and leather goods. ${ }^{47}$ None of his business dealings were of great value: a head of cattle was sold or bought for a small sum of money, is $\mathrm{fl}$., Is $\mathrm{fl}$. or sometimes only $9 \mathrm{fl} . .^{48}$ This impression of extremely meagre earnings is also reinforced by the mode of payment employed. As a rule, Mayer received the purchase price in an extremely complex instalment system which followed a specific temporal rhythm. The peasants agreed to pay off their debts "by autumn", i.e. the contracts were tied to the seasonal work and earning cycle of the agrarian economy. ${ }^{49}$ In the spring, before the approaching field work, older cows or horses were exchanged for newer animals, but payments were only made after the harvest. Thus extended periods of time for payments were often set in the contracts: for example, Magdalena Spitzer testified that she had already owed Mayer i4 $\mathrm{fl}$. for years, as the result of a horse deal, and that she now had agreed to repay him in several instalments ending on the "next fastnacht"..$^{\circ \circ}$ Although the protected Jew, Meyer, attempted to increase his

47. StaatsAA, Adel, Literalien, von Knöringen Herrschaft Binswangen no. 9, fos 22, 24, 28; no. 8, entries from 25.2.1669, 27.2.1669, 22.3.1671, 11.3.1671, 21.12.1672; no. 9, entry from 17.3.1677. 48. StaatsAA, Adel, Literalien, von Knöringen Herrschaft Binswangen no. 9, fo. 28, entries from 9.8.1680, 6.10.1680.

49. StaatsAA, Adel, Literalien, von Knöringen Herrschaft Binswangen no. 9, entry from 29.7.1678; fo. 28, entry from 31.12.1680; no. 8, entry from 27.2.1669:

5o. StaatsAA, Adel, Literalien, von Knöringen Herrschaft Binswangen no. 9, fo. 29. 
revenues as much as possible through the enormous selection of goods he offered and through his continual readiness to allow long-term payments on instalment, the protocol entries document his acute financial straits, which are reminiscent of those of the Ulmans in Pfersee. Between 1664 and 168I, he was summoned before the village court fourteen times by his credi-

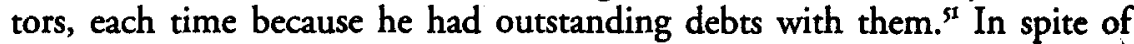
this, Meyer continued to be able to pay his taxes and to maintain his protected status for many years. As it was apparently impossible for him to accumulate even the smallest reserves for an emergency, several events lead to a dramatic worsening of his situation. In the winter of 1671 , he was forced to apologize in court to creditors for the fact that he had not been able make the instalment payments he had agreed to. He explained he had not been able to tend to business over the past weeks due to illness in his family: "His wife is said to have been deathly ill, as were the children, so that he was not able to leave his house" ${ }^{52}$ When, in 1672 , he was accused of breaches of regulations - including dealing in stolen goods - the authorities ordered the sale of his house and revoked their protection. He was finally saved from this acute threat by his brother-in-law, who lived in the neighbouring village of Buttenwiesen. The village court protocol records that because his brother-in-law "had spoken for him, he has been allowed into his house again". ${ }^{53}$ The brother-in-law, David, ultimately assumed the cost of the court proceedings, as well as Meyer's outstanding payments for protection money and imprisonment costs. From further entries in the village court protocol, we can conclude that in the following years Mayer repeatedly fell into financial difficulties. However, he does not appear to have been threatened with the repeal of his letter of protection again. In October 1680 one of his horses died while grazing. Mayer brought the herdsman before the village court, claiming that the animal "had drowned through his [the herdsman's] inattentiveness". Since the court did not grant his petition for "damages", 54 Meyer received no compensation for the costs arising from the loss of the animal. In view of the order of magnitude of his cattle deals, it is understandable that the loss of one animal must have been a significant setback for him, as was the fact that he was not able to engage in travelling sales for an extended period of time.

The factors which might prevent a family from being able to pay the necessary taxes and cause them to lose their protected status were thus manifold. They included the loss of a trade animal, illness and the death of

51. StaatsAA, Adel, Literalien, von Knöringen Herrschaft Binswangen no. 9, fos 22, 24, entries from 2.1.168I, 18.5.1674, 9.7.1674; no. 8, entries from 4.5.1664, 12.9.1664, 14.6.1678, 5.8.1668, 25.2.1669, 14.10.1670, 22.3.1671, 11.3.1671, 17.7.1671.

52. StaatsAA, Adel, Literalien, von Knöringen Herrschaft Binswangen no. 8, entry from 6.12.1671. 53. Ibid., entry from 21.12.1672.

54. StaatsAA, Adel, Literalien, von Knöringen Herrschaft Binswangen no. 9, entry from Io.10.1680. 
a spouse, and familial disputes which hindered the smooth operation of a small business. Since only a small minority of poorer households could make provisions for an emergency, even minor losses could have serious consequences for them.

\section{IV}

It thus remains all the more astounding that, despite the dangers described here, poor families were often able to maintain their protected status. Simon and Merle Ulman were veritable "survival artists" in this regard. In the end, however, they could no longer prevent the forced sale of their business as a result of their increasing debt. Yet, in spite of this, they were able to avoid losing their protection document. What patterns of behaviour emerge here? Where did the Ulmans receive support and what did their situation look like in the end?

In the course of the Ulmans' compulsory sale trial in July 1723, a long list of creditors and their demands was drawn up. This list also contains references to the support which the couple had received in the form of different kinds of loans. In spite of the Ulmans' increasing outstanding payments, Christian business partners repeatedly supplied goods for their business. In the end, the Ulmans owed the Augsburg businessmen, Johann Jakob Guttermann and Johann Jakob Kolb, a total of $800 \mathrm{fl}$. and $37 \mathrm{kr}$. Considering the order of magnitude of Simon's business deals, these loans must have been granted over a long period of time. Simon was also given numerous loans within the Pfersee Jewish community. He received $50 \mathrm{fl}$. from the community orphan coffers (Salomon Kitzinger demanded this amount as the "guardian of Samuel Weyl's heirs").5" David Jakob Ulman testified in the protocol of the trial that "among the loan-givers he must have suffered the greatest losses"..$^{56}$ Understandably, we are rarely able to identify intra-Jewish clientele relations - it was evidently a matter of such relations in Simon Ulman's case - from sources in the Christian province. In spite of this, such relations may have played an important role, given the significant differences in wealth within rural Jewish communities.

Social hierarchies were particularly pronounced within the Pfersee Jewish community. This community included a number of very wealthy families of "court Jews" - who had acquired their wealth by lending money and supplying goods to the rulers and armies of various royal courts in southern Germany $y^{57}$ as well as a whole series of families with no assets other than

55. StaatsAA, Reichsstadt Augsburg, Literalien, St. Jakobs Pfründe no. 207, fo. 108. See also fos 120, $127,137$.

56. Ibid., fo. 131 .

57. Mordechai Breuer and Michael Graetz (eds), Deutsch-Jüdische Geschichte in der Neuzeit 16001780, (Munich, 1996), pp. 106-I25; Friedrich Battenberg, Das europaische Zeitalter der Juden. Zur Entwicklung einer Minderheit in der nichtjüdischen Umwelt Europas, 2 vols (Darmstadt, 1990), vol. 
their houses. ${ }^{58}$ The functions of the elite group within the community's social and economic life can be traced through Lazarus Günzburger, Löw Simon Ulman (the Elder), and Salomon Kitzinger. In 1703, Günzburger who according to tax lists was by far the wealthiest member of the community - loaned Elias Ulma over 1500 fl., for which the latter pawned half of his house as well as his synagogue seats. ${ }^{99}$ In addition to this, Günzburger also functioned as business partner for retailers. In 1684, he imported coins valued at $350 \mathrm{fl}$. and distributed them among the Jewish merchants in the village as an advanced payment. The majority of household heads in Pfersee had borrowed money from him. ${ }^{60}$ This economic intertwining within the community would support the assumption that a well-organized network of intermediaries and negotiators, made up of the numerous Jewish cattle and goods merchants - for whom the court Jews functioned as buyers and wholesalers - was necessary in order to supply courts and armies with provisions on the order of magnitude we know to have been the case. ${ }^{65}$ To what degree Günzburger also made special contributions to the communal coffers for the poor is unclear. However, records regarding compulsory sales indicate that Salomon Kitzinger, the member of another wealthy family, functioned as the administrator of the guardianship coffers. And in 1755 Löw Simon Ulman (the Elder), one of the most important Pfersee court Jews of the eighteenth century, signed a contract together with Abraham Samson Model concerning the support of the village poorhouse, in which he assumed a large part of the costs involved. ${ }^{62}$ Turning to the support of wealthy fellow Jews was thus also possible - be it through the communal coffers for the poor and the orphan coffers, or through a direct loan.

In addition to this, the authorities also extended the term of payment for the Ulmans' protection money in the sum of $25 \mathrm{fl}$. $40 \mathrm{kr}$. - which accorded with the amount due for one year. This extension by the authorities fits with the tax policies, described earlier in this article, concerning widow households, and again illustrates that fiscal demands were by no means always immediately and rigorously applied. Simon Ulman was also given another reduction of his protection tax in $1724 .{ }^{63}$ Thus, at least for a limited period of time, the family was carried by the network of loans from business partners and from fellow Jews, as well as by the protection authorities who,

2, pp. 245-249; Jonathan I. Israel, European Jewry in the Age of Mercantilism I550-1750, (Oxford, 1985), pp. I23f.; Felix Priebatsch, "Die Judenpolitik des fürstlichen Absolutismus im 17. und I8. Jahrhundert", in Forschungen und Versuche zur Geschichte des Mittelalters und der Neuzeit. Festschrift fuir Dietrich Schäfer (Jena, 1915), pp. 564-651.

58. Ullmann, Nachbarschaft und Konkurrenz, pp. 360 .

59. StaatsAA, Adel, Literalien, von Langenmantel no. 34, fo. 13 .

60. StaatsAA, Reichsstadt Augsburg, Literalien, St. Jakobs Pfründe no. 202, fos 49, 614v.

6I. On comparable clientele and loan relationships in Christian travelling peddlers, see Laurence Fontaine, History of Pedlars in Europe (Cambridge, 1996), pp. 121-139.

62. StadtAA, St. Jakobs Pfründe, Fach 123 Fasz. A, fo. 34.

63. StadtAA, St. Jakobs Pfründe, Fach I18, Fasz. A, fo. I40. 
through a well-considered tax policy, allowed the family a certain temporal latitude.

When the Ulmans' debts could no longer be brought under control, even through clientele relations, it was ultimately the support of relatives which proved to be decisive - as had also been the case with Mayer from Binswangen cited above. Ulman's son-in-law, Sigmund Bacharach from Steppach, was prepared to buy the Ulman house for $1600 \mathrm{fl}$., and this intervention prevented the expulsion of the Jewish couple. With this, the Ulmans did lose the property rights to their house, but they were able to continue living in it and thus to retain their protection privileges in Pfersee. However, this support was not offered without services in return, but rather was tied to a series of concrete conditions and demands. The proceedings concerning the purchase of the house and the assumption of the Ulman debts reveal conflicts within the family as well as within the Jewish community.

The disputes here were marked by the fact that the total of the Ulmans' outstanding debts was significantly higher than the price agreed upon for their house ( $1500 \mathrm{fl}$.). As a result, protracted negotiations arose between creditors and potential buyers. After the first prospective buyer, Leb Ulman, decided not to purchase the house - evidently because of the magnitude of the debt - the Ulmans' son-in-law was, at least initially, the only potential buyer. The latter had to fend off the demands of creditors, which evidently exceeded his financial capacities as well. Initially, he doubted the legality of several of the debts. In a second step, he attempted to ward off the liability to the community which had arisen through Simon's pawning of the family's synagogue seats. There was a heated conflict on the matter between the son-in-law and Salomon Kitzinger who, as administrator of the community coffers, insisted on the return of the amount during the public auction proceedings. Sigmund Bacharach, on the contrary, claimed that the two seats should be included in the purchase price, as the house itself - according to his argument - was "not worth the purchase price, and no Jewish house had ever been purchased without synagogue seats" ${ }^{64}$ The son-in-law was finally able to work out a compromise. He paid only $50 \mathrm{fl}$. rather than the original demand of $75 \mathrm{fl}$., and the interest which had accrued on the payment was also waived."ss

After this point in the conflict had been settled, the dispute between Bacharach and Kitzinger again became extremely heated when, shortly before the purchase contract was to be signed, Kitzinger decided to make an offer on the house himself. Faced with the rigid limitation of protection privileges set by the Pfersee authorities - which since 1713 had consistently kept the number of protected Jewish households to twenty-eight, and had

64. StaatsAA, Reichsstadt Augsburg, Literalien, St. Jakobs Pfrüde no. 207, fo. 109.

65. Ibid., fo. 108 . 
refused to grant residency rights for further households ${ }^{66}$ - Kitzinger attempted to acquire property along with a protection document for his son by purchasing the Ulman house. In addition to this, he planned to build a new house on the property, thus enabling his son to establish his own household. The Pfersee court prevented this plan by maintaining a prohibition which had been issued in the fall of 1721 , according to which the Kitzinger family was forbidden from acquiring protection privileges for. "children and grandchildren" ${ }^{67}$ The occasion for this decree had been a conflict two years earlier regarding an honorary post within the synagogue, which had escalated to such a degree that it had not been possible to carry out an orderly election of the Jewish community leader. Because the dispute was thought to have called the authorities' power into question, Kitzinger who was regarded as a "ringleader" - was given this severe sanction. ${ }^{68}$ The sanction itself again clearly underlines the fact that Jewish population growth was a volatile issue, given the rigid limitation of the number of protected Jewish households in Pfersee.

This attempt by the wealthy Kitzinger family to expand its privileges at the expense of the Ulmans, by exploiting the latter's acute financial straits, was not successful. However, considering the significant social hierarchies within the Pfersee community, it was probably not an isolated occurrence. In her petition from 18 February 1727 , the Pfersee widow Rifga requested reduced protection money from the authorities, complaining that her husband had left her with six small children and that now "several people from the Jewish community intended to acquire the protection rights for themselves, and want to drive out myself with my poor abandoned orphan children" ${ }^{69}$ Life in the Jewish community consisted not only in various forms of assistance and economic connections; it also included a significant potential for conflict. In this regard, competition around the limited numbers of protection documents in the village could also become a dangerous risk for poorer members of the community.

The agreements which the son-in-law, Bacharach, finally made with Simon and Merle Ulman indicate further that support from relatives was not the expression of unselfish solidarity, but rather rested upon services in return. Communal relations, as well as relations to relatives, in other words, should not be misunderstood in terms of romantic clichés. Rather, they were characterized by reciprocities which again produced conflicts of their own. What did the contractual conditions for the purchase of the house look like in detail? First, Sigmund Bacharach had to agree to assume the debt contracts of his parents-in-law, and in future to pay the annual protec-

66. Ullmann, Nachbarschaft und Konkurrenz, pp. 8of.

67. StaatsAA, Reichsstadt Augsburg, Literalien, St. Jakobs Pfrüinde no. 207, fo. 130.

68. On this, see Ullmann, Nachbarschaft und Konkurrenz, pp. I83f.

69. StadtAA, St. Jakobs Pfrunde, Fach 118 Fasz. A, fo. I58. 
tion fees of $16 \mathrm{fl} .40 \mathrm{kr}$. for "as long as they live" $7^{\circ}$ In return, he secured free, lifelong living rights for a member of his own family, the sick and elderly husband of his dead sister. Merle Ulman also had to give him half the income from her business for seven years, and following this, one-third of her profits. Simon Ulman's business activities were not mentioned in this context, but rather only those of his wife. Since no more of Simon's trade contracts appear in the officials records after the summer of 1723 , but only further waivers of protection money, it is possible that Merle was able to establish his legal incapacity. Or perhaps Simon was no longer able to work due to illness.

By purchasing the house, the son-in-law from Steppach secured residency and business rights in Pfersee for his wife's family. This support, however, was only provided for the appropriate services in return: another needy family member - Bacharach's sick brother-in-law - was to be accommodated there, and Bacharach himself was to have a share in the Ulmans' business in the future. For Simon and Merle Ulman, assistance from relatives meant a lifeline in an extremely precarious situation. The assistance, however, was tied to new obligations and dependencies - this time to their son-in-law from Steppach.

What effects did the specific risks to Jewish existence and the strategies adopted by Jewish households to counter those risks have on the structure of rural Jewish families? Is it possible to derive typical characteristics for protected Jewish households from this?

One initial dimension might be the intensity of intrafamilial cooperation through which such families sought to improve their economic possibilities. The Jewish peddling trade could only function through the cooperation of all members of the household capable of working. This led to the great economic independence of Jewish women, an independence which was also evident in Jewish marital law. I recapitulate Merle Ulman's situation. She possessed a dowry of $400 \mathrm{fl}$. Her husband was able to use this money, but required her approval in order to do so, and had to pay the money back if they were divorced. Consequently, it was Merle who countersigned the debt contract for $50 \mathrm{H}$. with Andreas Wagner from Kaufbeuren, as she was the one who assumed liability for this sum with her own capital. In the course of their increasing debt, the couple not only lost their house, but Merle's dowry as well - both of these sums are recorded in the proceedings of public auction trial..$^{1}$ The loss of Merle's "female privilege" - which evidently occurred in steps through several debt contracts - was thus a result of the

70. StaatsAA, Reichsstadt Augsburg, Literalien, St. Jakobs Pfrïnde no. 207, fos 69-71.

71. Ibid., fo. 14 r. 
couple's financial plight. The use of her dowry, however, was not possible without her express consent, and in the contracts with her son-in-law, Merle continued to be treated as an independently acting business woman. Among rural Jews, the optimal use of all potential labour resources led to the largely autonomous economic position of wives, even if, in Merle's case, this economic autonomy was ultimately sacrificed to the necessities of the couple's economic plight. The conflicts in the Ulmans' marriage - which are documented in a number of places in the surviving records - might have had their origins here.

Jewish women found themselves in a particularly precarious situation following the death of their husbands. They were not always able to maintain their protected status and had to fight resistance from within their own community as well, i.e., it was often only possible for widows to lead an independent household for a limited period of time. This is perhaps the reason why widow households in rural Jewish society were something of an exception..$^{72}$ The compulsion to remarry or to transfer protection rights may have also been affected in the long run by the disparity between the very limited number of protected households permitted and the increase in population within the Jewish community.

In addition to the small number of widow households, there is a further peculiarity in the structure of Jewish families, one which was also the immediate consequence of protection practices and the result of specific counterstrategies developed by Jewish society: the comparatively large number of servants within Jewish households, even among poorer families. I offer a few numbers to illustrate this. According to the 1730 census, there were a total of thirty-five servants and maids living with sixty-three families in Kriegshaber, a Jewish settlement near Pfersee. Individual wealthy families, such as those of Moises and Lazarus Neuburger, had up to ten domestic servants. The families of Joseph Mändle and Abraham Mändle each had five servants within their households. Yet, in addition to these families of court Jews, the cantor Seeligmann, Alt Hitzig and Hitzig Levi, as well as the households in "altes Bäschenhaus" - which were among the poorest in the village - also employed maids and servants. Only thirteen families had no servants listed as members of their household. ${ }^{73} \mathrm{~A}$ census of the Jewish population in 1722 reveals a similar situation in Pfersee. In the thirty-one protected households, there were twenty-six servants. As one might expect, the court Jews had the greatest number of employees, but some of the less wealthy families also had a maid or a servant. Only the poorest families such as Simon and Merle Ulman (the Small), the three widow households,

72. Ullmann, Nachbarschaft und Konkurrenz, pp. 527-536. With four widow households in 1722 , the Pfersee community was an exception. Judging from my current knowledge of the sources, this was probably connected to the community's engagement in the pawn business, a typical enterprise for women and one which created a particularly favourable situation for them.

73. Ibid., p. 527 . 
the old butcher Leb, and Joseph Behr, as well as the cantor and the current butcher - were not in a position to have additional people live with them. ${ }^{74}$ In the case of Simon and Merle Ulman, however, this situation changed in 1723 after the conclusion of the public auction trial, when they had to take in their son-in-law's relative (who, however, was not yet listed in the census from 1722 ).

The large number of servants in Jewish families becomes understandable when we consider the origin of the people involved..$^{75}$ The restrictive policies in issuing protection documents meant that many families could not accommodate their children or related widows and widowers in their own village, and were thus compelled to find places for them in other communities. When a family could afford it, these people were often allowed to participate in the residency rights of relatives who took them in as "servants". The case of Lev Ulman's widow illustrates that people designated as "maids" or "servants" in the Christian tax lists were often not household employees in the actual sense of the term, but rather relatives. When Ulman's widow transferred her right of protection to her son, the administrator of the judicial authorities allowed this transfer - already mentioned earlier in the article - under the condition that "the mother gives up her protection and remains as a maid" ${ }^{76}$ Thus the language of the authorities found a category for this specific Jewish phenomenon, which was then adapted to Christian linguistic traditions. At the same time, the example of Simon and Merle Ulman shows that solidarity among relatives did not always occur voluntarily, but could also be the expression of financial difficulties within that household. If this taking-in of relatives was voluntary, then each household had to weigh how much a particular "servant" would require in additional food, or how much that servant could contribute to the household as a whole. On the basis of existing sources, we are not able to determine whether this contribution consisted in work, money or a portion of business profits earned.

The small number of widow households and the large number of servants are indications of the same phenomenon, i.e., the attempt to accommodate as many people as possible within a single household. This increased size of protected households accords with a strategy worked out within Jewish society, a strategy which sought to expand the letter of protection issued to the head of a household so as to include a broad circle of people and thus to evade restrictive Jewish policies. The case of Simon and Merle Ulman

74. Ibid., pp. $535-539$.

75. On the composition of protected Jewish households and the "hidden" population in the late Middle Ages, see Michael Toch, "Die soziale und demographische Struktur der jüdischen Gemeinde Nürnbergs im Jahre 1489 ", in Jürgen Schneider (ed.), Wirtschaftskräfte und Wirtschaftswege. Festschrift für Hermann Kellenbenz (Stuttgart, 198I) pp. 79-91, 82f. For the early modern period, see Sabelleck, Jiudisches Leben, pp. 82-88.

76. StadtAA, St. Jakobs Pfründe, Fach iı8 Fasz. A, fo. I6I. 
indicates that the concrete manifestations of this basic structural tendency produced a variety of conflicts on a communal as well as a familial level.

An increase in the members of a household, however, did not necessarily mean that these members also made up a single economic unit or that they were all integrated within the family business run by the head of the household. Rather, Jewish servants also operated independent businesses - a practice which was forbidden by the authorities. The fact that Jewish servants made independent contributions to households is indicated by the decrees issued regarding such activities. In January 1699 the authorities in Pfersee felt it necessary to enact a mandate concerning "the Jewry's servants", which ordered that "servants should refrain from all private trading", ${ }^{77}$ since the privilege of operating an independent business was tied to the possession of a separate document of protection. The activities of Jewish servants and maids are actually documented numerous times in the official protocols. When, in April 1738, the maidservant Vögele moved to Oettingen from Pfersee, where she had lived in the household of Elias Heium, she attempted to settle the unpaid debts from her pawn business. She was able to pass on a portion of the deposits to a Jewish man named Joseph, who was employed by David Ulman as the schoolteacher - for example, the $161 / 2$ ells of black cloth which a woman from Augsburg had left with her for 10 f.$^{78}$ Similarly, the independent pawn deals of a servant named Isaak Meyer are also documented in the records: in 1726, a shopkeeper's daughter from Augsburg pawned her inferior jewellery with him for $5 \mathrm{f} . .^{79}$ And in Binswangen, Rubin Gerstle, who was employed in Leb Jonas's household, bought seeds from a peasant in Bonstetten for $9 \mathrm{f}$. in May $1740 .^{80}$ In the autumn of that same year, he reported to officials the peasant owed him $20 \mathrm{fl}$. Is $\mathrm{kr}$. from a deal in leather goods. ${ }^{8 \mathrm{x}}$

The relatively independent economic status of servants within protected Jewish households in the countryside again accords with the particular conditions of Jewish existence there, and the external pressures exerted upon that society. On the one hand, as many people as possible attempted to participate in the protected status of a household; on the other hand, the small trade businesses could hardly provide everyone in the household with a livelihood, so that independent economic opportunities had to be exploited as well - by wives as well as by "servants" and "maids". In all probability, however, there was a qualitative difference between the cooperative work organization between husbands and wives within the peddling business and the activities of servants, which were probably significantly more independent. Yet both forms arose from the same strategy, a strategy

77. Ibid, fo. 24.

78. StaatsAA, Reichsstadt Augsburg, Literalien, St. Jakobs Pfrinde no. 210, fo. 495.

79. StaatsAA, Reichsstadt Augsburg, Literalien, St. Jakobs Pfründe no. 207, fo. 505.

80. StaatsAA, Adel, Literalien, von Knöringen Herrschaft Binswangen no. 26, fo. 120.

8I. Ibid., fo. 151 . 
which can be expressed as follows: as much residential unity as possible so as to enable the optimal exploitation of a protection document, combined with great economic independence for the individual members of the household. As a result, Jewish households were not set economic and social units, but rather were characterized by a certain independence for individual members. In the battle for survival, the composition of the households could be altered. However, we must also bear in mind that our reflections on the size of Jewish families as well as on the inner structure of the "household economy" always moves in a grey zone, due to the peculiarity of existing sources. In this sense, I understand my interpretation as an initial approach to a complex reality, a reality which can only be grasped with difficulty. Finally, differences between Jewish and Christian worlds should not be overemphasized, as networks of relatives, the necessity of replacing role functions in widows' households and the vocational activity of women as conditioning factors of early modern familial forms were also components of Christian agrarian societies. ${ }^{82}$

Translated by Thomas Lampert

82. Michael Mitterauer, Historisch-anthropologische Familienforschung. Fragestellungen und Zugangsweisen, Kulturstudien is (Vienna [etc.], 1990), pp. 131-141. 